\title{
Evaluation of Alternate Insecticides for the Management of Rhinoceros Beetle,(Oryctes rhinoceros L.) in Coconut Ecosystems
}

\author{
T. Srinivasan* and N. Shoba \\ Coconut Research Station, \\ Tamil Nadu Agricultural University, \\ Aliyarnagar, Coimbatore (Dt.) Tamil Nadu
}

\begin{abstract}
Young coconut palms in the age group of one to six years are frequently succumbed to attack in the crown region especially the spear leaf due to rhinoceros beetles. Damage by the beetle results in ' $V$ ' shaped cuts in the leaf lamina and repeated attacks by the pest results in reduced leaf area for photosynthesis. The available insecticide for the management of rhinoceros beetles viz., phorate, carbofuran, etc. though effective, are found to be toxic to non target organisms and hence alternate insecticides were evaluated for the management of the black beetles. Among the different insecticides tested in farmers fields, chlorpyriphos $1.5 \% \mathrm{DP}$ and chlorantraniliprole $0.4 \%$ GR insecticides along with 100-150 gram of sand are effective in reducing the leaf and spindle damage as effective as phorate $10 \mathrm{G}$ insecticide. Considering the harmful nature of phorate, insecticides viz., chlorantranliprole and chlorpyriphos can be recommended for the management of rhinoceros beetle in coconut ecosystems which are both efficacious as well as cost effective
\end{abstract}

Key words: Coconut rhinoceros beetle, Insecticides, Evaluation

India is one of the three largest coconut producing countries of the world followed by Indonesia and Philippines. Coconut is cultivated in an area of 21.4 lakh ha in India and has an average productivity of 10,119 nuts/ha (CDB, 2014). Among the various insect pests causing damage to coconut, rhinoceros beetle, Oryctes rhinoceros (L.) is a serious pest in South East Asia (Bedford, 2013), infesting preferably young coconut palms in the age group of one to six years. The adult beetles cause injury to the young palms by boring into the central spindle leaf, spathe and young petioles. An estimated yield loss of $10 \%$ is attributed to spathe damage by rhinoceros beetles. The adult beetle feeds on the soft tissues and the chewed up fibrous material is seen protruding from the entry point or the bore holes (Nirula, 1955). The spindle leaf is thus prone to breakage and drying up. The damaged spindle leaf when unfurls exhibit " $V$ " shaped cuts on the leaf lamina. Repeated attacks by the pest results in stunted growth or mortality at times (Hinckley, 1966; Giblin-Davis, 2001). In majority of the cases, rhinoceros beetle attack leads to infestation by red palm weevil, fungal infections, etc. leading to death of the coconut palms (Molet, 2013). The female adults oviposit about 50-100 eggs, on the decaying logs of wood or manure pits (Bedford, 1980). The emerging larva survives in the manure pits or decomposing organic matter for three to six months. The adults upon emergence go in search of young palm crowns for feeding during night while remaining in the breeding sites during day time. The adults live for another four to six months

*Corresponding author email: entosrini@gmail.com during which time causes enormous damage to the younger palms. The pest could be kept under check by using integrated management options including cultural, mechanical, biological and chemical control measures. With regard to usage of insecticides, phorate and carbofuran are being applied in the crown region by farmers to get rid of the pest. However, due to the toxic nature of the granular insecticides to non target organisms, the present study was conducted to identify alternate insecticides for the management of rhinoceros beetles.

\section{Material and Methods}

The field experiments for the management of rhinoceros beetles were carried out in the farmer's fields in the surroundings of Pollachi region. Gardens with young palms infested by rhinoceros beetle were selected for imposing the treatments (Table 1). Two trials were laid out one at Avalchinnampalayam, Anaimalai block (2013-14) and another at Pongaliyur Anaimalai block (2015-16). The garden at Avalchinnampalayam was five years old (Var: Chowghat Orange Dwarf) and the garden at Pongaliyur was 3 years old (Var: private hybrid) at the time of laying out the experiments. The treatments were imposed as per the schedule provided in the table. All the treatments (insecticides/ botanicals) were made on the crown region on the innermost three leaf axil beneath the spindle leaf along with $100-150 \mathrm{~g}$ of fine sand as a carrier. The experiments were conducted in a Randomized Block Design (RBD) with eight treatments and three replications (4 palms/ replication). Observations on the leaf and spindle 
damage were recorded at quarterly intervals and expressed as level of damage after 12 months. The intensity of coconut rhinoceros beetle was recorded in terms of spindle and leaf damage prior to imposing treatments and after imposing treatments at quarterly intervals. The per cent leaf damage is calculated using the following formula.

Per cent leaf damage $=\frac{\text { No. of damaged leaves }}{\text { Total number of leaves }} \times 100$
A damaged spindle corresponds to cent per cent spindle damage, while a spindle free of infestation is recorded as 0 per cent spindle damage. The data obtained were subjected to appropriate transformation and analysed using least significant difference.

\section{Results and Discussion}

At the first location viz., Avalchinnampalayam, the initial level of leaf damage ranged from 29.1 to 44.5 per cent in different treatments before imposing the treatments.

Table 1. Particulars of the treatments for rhinoceros beetle management

\begin{tabular}{clc}
\hline Treatments & \multicolumn{1}{c}{ Particulars } & $\begin{array}{c}\text { Frequency of the } \\
\text { treatments }\end{array}$ \\
\hline T1 & Mechanical removal of adult beetles using iron hook & Once in a month \\
T2 & Placement of naphthalene balls in powder form $(12 \mathrm{~g} / \mathrm{palm})$ mixed with $100-150 \mathrm{~g}$ sand & \\
T3 & Placement of whole naphthalene balls @ 3 nos./ palm (each weighing 3-4 grams) & Once in two \\
T4 & Placement of phorate $10 \%$ CG granules @ $10 \mathrm{~g} /$ palm mixed with 100-150 g sand & months \\
T5 & Placement of chlorantraniliprole 0.4\% GR @ 5 g/ palm mixed with 100-150 g sand & \\
T6 & Placement of chlorpyriphos $1.5 \%$ DP dust @ 5 g/ palm mixed with 100-150 g sand & \\
T7 & Placement of neem cake $(100 \mathrm{~g})$ mixed with 100-150 g sand & \\
T8 & Untreated control (sand alone) & \\
\hline
\end{tabular}

At 15 months after treatment, chlorantraniliprole registered the least leaf damage (12.1\%) followed by phorate $(13.0 \%)$, naphthalene ball powder $(14.1 \%)$ and chlorpyriphos (14.4\%) which were on par with each other, while the control registered a leaf damage of 37.5 per cent (Table 2).

Table 2. Impact of different treatments on the leaf damage due to rhinoceros beetle in coconut

\begin{tabular}{|c|c|c|c|c|c|}
\hline \multirow[t]{2}{*}{ Trt. } & \multirow[t]{2}{*}{ Treatments } & \multicolumn{2}{|c|}{ Location I Avalchinnampalayam } & \multicolumn{2}{|c|}{ Location II Pongaliyur } \\
\hline & & PTC & 15 MAT & PTC & 12 MAT \\
\hline \multirow[t]{2}{*}{ T1 } & \multirow[t]{2}{*}{ Mechanical removal } & 30.9 & $25.1 \mathrm{~cd}$ & 47.7 & $40.9 \mathrm{e}$ \\
\hline & & $(33.8)$ & $(30.1)$ & $(43.7)$ & $(39.8)$ \\
\hline \multirow[t]{2}{*}{ T2 } & \multirow{2}{*}{$\begin{array}{l}\text { Naphthalene balls in powder } \\
\text { form }(12 \mathrm{~g} / \text { palm })\end{array}$} & 43.0 & $14.1 \mathrm{ab}$ & 49.0 & $25.6 \mathrm{~d}$ \\
\hline & & $(41.0)$ & $(22.1)$ & $(49.0)$ & $(30.4)$ \\
\hline \multirow[t]{2}{*}{ T3 } & \multirow{2}{*}{$\begin{array}{l}\text { Full naphthalene balls ( } 3 \\
\text { nos./palm) }\end{array}$} & 29.1 & $17.5 \mathrm{abc}$ & 40.2 & $20.3 \mathrm{bcd}$ \\
\hline & & $(32.7)$ & $(24.7)$ & (39.3) & $(26.8)$ \\
\hline \multirow[t]{2}{*}{ T4 } & \multirow[t]{2}{*}{ Phorate 10CG @ 10 g/palm } & 44.5 & $13.0 \mathrm{ab}$ & 41.5 & $14.5 \mathrm{abc}$ \\
\hline & & $(41.8)$ & $(21.1)$ & $(40.1)$ & $(22.4)$ \\
\hline \multirow[t]{2}{*}{ T5 } & \multirow{2}{*}{$\begin{array}{l}\text { Chlorantraniliprole 0.4GR @ } \\
5 \mathrm{~g} / \text { palm }\end{array}$} & 32.8 & $12.1 \mathrm{a}$ & 39.0 & $15.4 a b$ \\
\hline & & (34.9) & $(20.4)$ & $(38.6)$ & $(23.1)$ \\
\hline \multirow[t]{2}{*}{ T6 } & \multirow{2}{*}{$\begin{array}{l}\text { Chlorpyriphos 1.5DP @ } 5 \\
\text { g/ palm }\end{array}$} & 39.3 & $14.4 \mathrm{abc}$ & 47.9 & $9.8 \mathrm{a}$ \\
\hline & & $(38.8)$ & $(22.3)$ & $(43.8)$ & $(18.2)$ \\
\hline \multirow[t]{2}{*}{$\mathrm{T7}$} & \multirow[t]{2}{*}{ Neem cake @ 100 g/ palm } & 30.7 & $22.8 \mathrm{bc}$ & 43.4 & $22.1 \mathrm{~cd}$ \\
\hline & & $(33.6)$ & $(28.5)$ & $(41.2)$ & $(28.0)$ \\
\hline \multirow[t]{5}{*}{ T8 } & \multirow[t]{2}{*}{ Untreated control } & 44.4 & $37.5 \mathrm{~d}$ & 42.3 & $52.2 \mathrm{f}$ \\
\hline & & $(41.8)$ & $(37.8)$ & $(40.6)$ & $(46.3)$ \\
\hline & Significance & NS & ** & NS & $* *$ \\
\hline & CD (5\%) & - & 7.9 & - & 5.3 \\
\hline & CV (\%) & & 17.8 & - & 10.3 \\
\hline
\end{tabular}

IPTC - Pre-treatment count; MAT - Months after treatment; * - Significant at $5 \%$ level; ** - Significant at $1 \%$ level; NS - Not significant

Figures in parenthesis are arc sine transformed values; Values followed by a common letter are not significantly by LSD $(P=0.05)$ 
The efficacy of chlorantraniliprole in reducing stem borer and leaf folder infestation has been proved by Suri and Brar (2013). The use of chlorpyriphos dust and neem cake has been already proved effective against rhinoceros beetle by Josephrajkumar et al. (2012). Mohan and Padmanaban (2013) also documented the antifeedant and deterrent activities of neem cake against rhinoceros beetles. The effects of naphthalene balls was also proved by Yamini Varma (2013) and Sadakathullah and Ramachandran (1990) which repelled the adults of rhinoceros beetles up to 45 days. At the second location viz., Pongaliyur also, almost similar results were obtained in terms of reduction in leaf damage by rhinoceros beetle. The leaf damage before imposing the treatments ranged from 39.0 per cent to 49.0 per cent. After 12 months of imposing treatments, chlorpyriphos registered the least leaf damage $(9.8 \%)$ followed by phorate $(14.5 \%)$ and chlorantraniliprole $(15.4 \%)$, while the control palms exhibited a leaf damage of 52.2 per cent.

Table 3. Impact of different treatments on the leaf damage due to rhinoceros beetle in coconut

\begin{tabular}{llcccc}
\hline \multirow{2}{*}{ Trt. } & \multicolumn{1}{c}{ Treatments } & \multicolumn{2}{c}{$\begin{array}{c}\text { Location I } \\
\text { Avalchinnampalayam }\end{array}$} & \multicolumn{2}{c}{$\begin{array}{c}\text { Location II } \\
\text { Pongaliyur }\end{array}$} \\
\cline { 3 - 6 } & & PTC & 15 MAT & PTC & $12 \mathrm{MAT}$ \\
\hline T1 & Mechanical removal & 41.7 & 58.3 & 33.3 & $50.0 \mathrm{ab}$ \\
& & $(40.2)$ & $(49.8)$ & $(35.2)$ & $(45.0)$ \\
T2 & Naphthalene balls in powder & 50.0 & 16.7 & 33.3 & $25.0 \mathrm{a}$ \\
& form (12 g/ palm) & $(45.0)$ & $(24.1)$ & $(35.2)$ & $(30.0)$ \\
T3 & Full naphthalene balls (3 & 50.0 & 16.7 & 50.0 & $33.3 \mathrm{a}$ \\
& nos./palm) & $(45.0)$ & $(24.1)$ & $(45.0)$ & $(35.2$ \\
T4 & Phorate 10CG @ 10 g/palm & 66.7 & 16.7 & 58.3 & $33.3 \mathrm{a}$ \\
& & $(54.8)$ & $(24.1)$ & $(49.8)$ & $(35.2)$ \\
T5 & Chlorantraniliprole 0.4GR @ & 58.3 & 8.3 & 25.0 & $16.7 \mathrm{a}$ \\
& 5 g/ palm & $(49.8)$ & $(16.7)$ & $(30.0)$ & $(24.1)$ \\
T6 & Chlorpyriphos 1.5DP @ 5 g/ & 66.7 & 16.7 & 25.0 & $16.7 \mathrm{a}$ \\
& palm & $(54.8)$ & $(24.1)$ & $(30.0)$ & $(24.1)$ \\
T7 & Neem cake @ 100 g/ palm & 66.7 & 50.0 & 33.3 & $33.3 \mathrm{a}$ \\
& & $(54.8)$ & $(45.0)$ & $(35.2)$ & $(35.2)$ \\
T8 & Untreated control & 75.0 & 50.0 & $53.3 \mathrm{~b}$
\end{tabular}

PTC - Pre-treatment count; MAT - Months after treatment

* - Significant at $5 \%$ level; ** - Significant at $1 \%$ level; NS - Not significant

Figures in parenthesis are arc sine transformed values

Values followed by a common letter are not significantly by LSD $(P=0.05)$

With respect to spindle damage, different treatments exhibited 41.7 to 75.0 per cent spindle damage before imposing the treatments in the Avalchinnamplayam trial plot ((Table 3). At 15 months after treatment, though there was no significant difference among the different treatments in reducing the spindle damage chlorantraniliprole exhibited the least spindle damage $(8.3 \%)$ followed by chlorpyriphos, phorate and naphthalene balls (both powder form and whole balls) $(16.7 \%)$, while 50 per cent spindle damage was recorded in control. The effects of naphthalene balls, neem cake, etc. in reducing the spindle damage was earlier proved by Singh (1987) and Chandrikamohan et al. (2010). Reduction in spindle damage could be the result of the repellent action of naphthalene balls placed in the innermost leaf axils. Application of naphthalene balls at 10-12 $\mathrm{g} / \mathrm{palm}$ at the base of the three top-most leaf sheath at 45 days interval helped in preventing rhinoceros beetle entry at crown region (Sadakathulla and Ramachandran, 1990) and they have attributed this phenomenon to the repellant action provided by naphthalene balls against rhinoceros beetle adults. In the second location (Pongaliyur) also, a similar trend in the reduction of spindle damage was noticed. The initial level of spindle damage was 25.0 to 50.0 per cent in different treatments. At 12 months after treatment, chlorantraniliprole and chlorpyriphos recorded the least spindle damage $(16.7 \%)$ followed by naphthalene balls (powder form) $(25.0 \%)$ while phorate, whole naphthalene balls and neem cake exhibited 33.3 per cent spindle damage when compared to 83.3 per cent damage in the control. Generally, spindle damage is one of the pre-disposing factors for crown infestation by red palm weevil. Mostly, red palm weevil infestation in the 
crown region goes unnoticed until advanced stages, and the crown topples under severe infestation. Thus, by avoiding rhinoceros beetle attack in the crown region, the secondary attack by red palm weevil can be prevented to a considerable extent.

Table 4. Cost of different treatments used in the experiment

\begin{tabular}{lcc}
\hline Treatment & Dose/ palm (g) & Treatment cost / palm (Rs.) \\
\hline Mechanical removal @ Rs. 4/palm & -- & 4.00 \\
Naphthalene balls powder @ Rs. 260/kg & 50 & 3.12 \\
Full naphthalene balls @ Rs. 260/kg & 5 & 3.12 \\
Phorate 10CG @ Rs. 90/kg & 5 & 0.90 \\
Chlorantraniliprole 0.4GR @ Rs.195/kg & 10 & 0.98 \\
Chlorpyriphos 1.5DP @ Rs. 60/kg & 10 & 0.30 \\
Neem cake @ Rs. 25/kg & 100 & 2.50 \\
Untreated control & -- & -
\end{tabular}

From the above discussion it could be concluded that, chlorantraniliprole and chlorpyriphos could be effectively used as alternate insecticides in the wake of the ban imposed for phorate insecticides. However, an analysis on the cost of insecticides used in the experiments revealed that, chlorpyriphos was comparatively cost effective (Rs.0.30/ palm) followed by phorate (Rs.0.90/ palm) and chlorantraniliprole (Rs.0.98/ palm) (Table 4). Though neem cake and naphthalene balls were effective, they incurred a cost of Rs. 2.50 and Rs. 3.12, respectively. Considering the lesser cost involved, chlorpyriphos and chlorantraniliprole can be used for the management of rhinoceros beetles in coconut ecosystems.

\section{Conclusion}

Studies conducted at farmers' fields of Anaimalai block, Coimbatore district, Tamil Nadu, revealed that, chlorantarniliprole @ 5g/palm or chlorpyriphos @ 5g/palm could be used for crown application at 60 days interval, as alternatives, in place of phorate, naphthalene balls and neem cake which are presently used against rhinoceros beetles. The above mentioned insecticides could be considered for the management of rhinoceros beetles in coconut ecosystem both in terms of efficacy as well as cost effectiveness.

\section{Acknowledgment}

The critical suggestions made by the Director, Centre for Plant Protection Studies, TNAU, Coimbatore, Professor and Head, TNAU, Coimbatore is gratefully acknowledged.

\section{References}

Bedford, G.O. 2013. Long term reduction in damage by rhinoceros beetle, Oryctes rhinoceros L. (Coleoptera: Scarabaeidae: Dynastinae) to coconut palm at Oryctes Nudivirus release sites on Viti Levu, Fiji. Afr. J. Agric. Res. 8: 6422.
CDB, 2014. http://coconutboard.nic.in/stat.htm.

Chandrikamohan, Rajan, P., Nair, C.P.R., Thomas, T. and Anithakumari, P. 2010. Farmer friendly production technology of the green muscardine fungus for the management of rhinoceros beetles. Indian Coconut J. Nov 2010, pp 27-30.

Giblin-Davis , R.M. 2001. Borers of Palms. In: Howard, F. W., Moore, D., Giblin-Davis, R. M. and Abad, R. G. [eds.] Insects on Palms. CABI Publishing. p: 267-304.

Hinckley, A. D. 1966. Damage by the rhinoceros beetle, Oryctes rhinoceros (L.) to Pacific island. Palms South Pac. Bull. 16: 51-52.

Josephrajkumar, A., Chandrikamohan, Rajan, P., Thomas, R.J., Chandramohanan, R. and Jacob, P. M. 2012. Pest Management in Coconut Nursery, Technical Bulletin No., 73, ICAR-CPCRI, Kasaragod, p: 16

Mohan, K. and Padmanaban, M. 2013. Biotoxicity assay of neem (Azadirachta indica) products and distillery effluent on the third instar larvae of coconut rhinoceros beetle, Oryctes rhinoceros. Int. J. Pharma Biosci. 4(4): 102-110.

Molet, T. 2013. CPHST Pest datasheet for Oryctes rhinoceros, USDA-APHIS-PPQ-CPHST, p: 14

Nirula, K.K. 1955. Investigations on the pests of coconut palm II. Oryctes rhinoceros L. Indian Coconut J. 88: 161-180.

Sadakathulla, S. and Ramachandran, T. K. 1990. Efficacy of naphthalene balls in the control of rhinoceros beetle attacks in coconut. Cocos, 8: 23-25.

Singh, G. 1987. Naphthalene balls for the protection of coconut and oil palms against Oryctes rhinoceros. Planter, 63: 286-292.

Suri, K.S. and Brar, D.S. 2013. Bioefficacy of chlorantraniliprole against stem borers and leaf folder infesting Basmati rice. Indian J. Pl. Prot., 41(3): 215-218.

Yamini Varma, C.K. 2013. Efficacy of ecofriendly management against rhinoceros beetle grubs in coconut. J.Biopest. 6(2): 101-103. 